\title{
Functional activities of beta-glucans in the prevention or treatment of cervical cancer
}

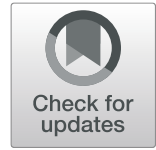

\author{
Shahla Chaichian ${ }^{1}$, Bahram Moazzami ${ }^{1}$, Fatemeh Sadoughi ${ }^{*}$, Hamed Haddad Kashani ${ }^{3}$, Marsa Zaroudi ${ }^{4}$ and \\ Zatollah Asemi ${ }^{2^{*}}$
}

\begin{abstract}
Cervical cancer is the fourth-ranked cancer in the world and is associated with a large number of deaths annually. Chemotherapy and radiotherapy are known as the common therapeutic approaches in the treatment of cervical cancer, but because of their side effects and toxicity, researchers are trying to discovery alternative therapies. Betaglucans, a group of glucose polymers that are derived from the cell wall of fungi, bacteria, and etc. it has been showed that beta-glucans have some anti-cancer properties which due to their impacts on adaptive and innate immunity. Along to these impacts, these molecules could be used as drug carriers. In this regard, the application of beta-glucans is a promising therapeutic option for the cancer prevention and treatment especially for cervical cancer. Herein, we have summarized the therapeutic potential of beta-glucans alone or as adjuvant therapy in the treatment of cervical cancer. Moreover, we highlighted beta-glucans as drug carriers for preventive and therapeutic purposes.
\end{abstract}

Keywords: Beta-glucans, Cervical cancer, Anti-cancer, Treatment, Prevention, Sizofiran

\section{Introduction}

Cervical cancer is known as the fourth cancer among women and the eighth common cancer worldwide [1, 2]. Cervical cancer is a result of being infected by some types of human papillomavirus or HPV, which are effective on the mucosa [3, 4]. Findings indicated that HPV is a necessary cause of cervical cancer; this means that the other risk factors can increase the risk of cervical cancer, but they are not able to develop this kind of cancer in the absence of HPV [5]. In this regard, potential cofactors involved in the cervical cancer pathogenesis are divided into three classes: 1 ) Environmental risk factors such as using hormonal birth control [6, 7], smoking [8], parity (the number of sex partners) [9], and have a history of being infected with other sexually transmitted agents [10-12].

\footnotetext{
* Correspondence: rahasadoughi@gmail.com; asemi_r@yahoo.com ${ }^{2}$ Research Center for Biochemistry and Nutrition in Metabolic Diseases, Kashan University of Medical Sciences, Kashan, I.R, Iran

Full list of author information is available at the end of the article
}

2) Viral risk factors including having a history of being infected with other HPV types, viral load, and integration of several viruses [13]. 3) Host risk factors like endogenous hormones, genetic-related factors, and generally any factor that can affect on the response of the immune system [13].

It has been indicated that a variety of therapies could be used in the treatment of different cancers such as cervical cancer. In this word, many therapeutic approaches i.e., surgery, chemo, and radiotherapy, utilization of immune checkpoint inhibitors, therapeutic vaccines, and antibody-drug conjugates, gene- and cell-based therapy, and nanotechnology-based therapies could be employed as primary lines of therapy in the cancer therapy [1420]. Given that some of the above approaches such as surgery, chemo and radiotherapy, vaccine- and antibodybased therapies have therapeutic candidates in the cervical cancer therapy [21]. 
Glucans are a kind of polymers that are made up of glucose monomers alone and are known as a heterogeneous class of polysaccharides. These glucose polymers are different from each other in some properties such as their chain length, having branches, being alpha or beta isomers and their ability to dissolve [22]. Beta-glucans can be found in different plants such as oat, barley, and seaweed. In addition, they are also involved in fungal and pathogenic bacterial cell walls [23]. Cellulose, curdlan, laminarin, chrysolaminarian, lentinan, lichenin, pleuran, zymosan, and schizophyllan are some examples of betaglucans (Table 1) [60]. These glucose polymers could be linked together by $\beta(1 \rightarrow 3)$ linkages and provide the linear $\beta$-glycosidic chain core [61]. The glycosidic core could provide different kinds of branches. Two important groups of them are $1 \rightarrow 4$ or $1 \rightarrow 6$ glycosidic chains [62].
Diverse structures of beta-glucans can proceed from different resources. For instance, beta-glucans derived from oat and barley are linear with large regions of beta $(1,4)$ linkages separating shorter stretches of beta $(1,3)$ structures while beta-glucans of mushrooms have short branches with beta $(1,6)$-link coming off of the beta $(1,3)$ backbone. Yeast beta-glucans have beta $(1,6)$ branches that are further intricate with additional beta $(1,3)$ regions. These diversities in the beta-glucan structures are the reason why they have different functions. The biological functions of beta-glucans depend on their interaction with their receptors. These interactions are also dependent on two factors including conformation of these molecules and their water solubility. It is acknowledged that the water-soluble glucans are more efficient [63].

Table 1 Different beta-glucans, their characteristics, sources, and potential uses

\begin{tabular}{|c|c|c|c|c|c|}
\hline Name of beta-glucan & Type & Source & Characteristic (s) & Potential application (s) & References \\
\hline Cellulose & Beta-1,3-glucan & $\begin{array}{l}\text { Plant and bacterium } \\
\text { (Acetobacter species) }\end{array}$ & $\begin{array}{l}\text { Insoluble in water, } \\
\text { straight-chain, high } \\
\text { mechanical strength, }\end{array}$ & Wound-dressing & {$[24-28]$} \\
\hline Curdlan & Beta-1,4-glucan & $\begin{array}{l}\text { Bacterium } \\
\text { (Agrobacterium species) }\end{array}$ & $\begin{array}{l}\text { Water-insoluble, } \\
\text { linear, high molecular } \\
\text { weight, affecting } \\
\text { innate and adaptive } \\
\text { immunities, easy } \\
\text { modification }\end{array}$ & $\begin{array}{l}\text { Immunological functions } \\
\text { and drug delivery }\end{array}$ & {$[29-33]$} \\
\hline Laminarin & $\begin{array}{l}\text { Beta-1,3 and } \\
\text { beta-1,6-glucan }\end{array}$ & Brown algae & $\begin{array}{l}\text { Low molecular } \\
\text { weight, linear, low } \\
\text { viscosity, antioxidant, } \\
\text { and antimicrobial } \\
\text { activities }\end{array}$ & $\begin{array}{l}\text { Development of a new } \\
\text { injectable system }\end{array}$ & {$[34-37]$} \\
\hline Chrysolaminarian & Beta-1,3-glucan & Microalgae & $\begin{array}{l}\text { Linear, antioxidant } \\
\text { and immunomodulatory } \\
\text { capacity suitable for } \\
\text { immunostimulation }\end{array}$ & $\begin{array}{l}\text { Development of a } \\
\text { new injectable }\end{array}$ & {$[38,39]$} \\
\hline Lentinan & $\begin{array}{l}\text { Beta-1,3 and } \\
\text { beta-1,6-glucan }\end{array}$ & Fungus (Shiitake) & $\begin{array}{l}\text { Affecting } T \text { helpers } \\
\text { and macrophage, } \\
\text { non-toxic and } \\
\text { well-tolerated } \\
\text { immunomodulator, } \\
\text { initiating an } \\
\text { inflammatory } \\
\text { response }\end{array}$ & $\begin{array}{l}\text { Anti-tumor effects } \\
\text { with low side effects }\end{array}$ & {$[40-43]$} \\
\hline Lichenin & $\begin{array}{l}\text { Beta-1,3 and } \\
\text { beta-1,4-glucan }\end{array}$ & $\begin{array}{l}\text { Lichens } \\
\text { (Cetraria islandica) }\end{array}$ & $\begin{array}{l}\text { Linear, non-toxic, } \\
\text { stimulating effects } \\
\text { on T cells }\end{array}$ & $\begin{array}{l}\text { Being used as an } \\
\text { Anti-tumor agent }\end{array}$ & {$[44-46]$} \\
\hline Pleuran & $\begin{array}{l}\text { Beta-1,3 and } \\
\text { beta-1,6-glucan }\end{array}$ & $\begin{array}{l}\text { Fungus } \\
\text { (Pleurotus ostreatus) }\end{array}$ & $\begin{array}{l}\text { Immunomodulatory } \\
\text { and anti-inflammatory } \\
\text { activity }\end{array}$ & $\begin{array}{l}\text { Treatment of dermatitis, } \\
\text { being used as an anti-cancer } \\
\text { and anti-allergic agent }\end{array}$ & {$[47-51]$} \\
\hline Zymosan & Beta-1,3-glucan & Yeast & $\begin{array}{l}\text { Anti-inflammatory } \\
\text { effects, affecting } \\
\text { dendritic and T } \\
\text { cells, affecting } \\
\text { cytokine expression }\end{array}$ & $\begin{array}{l}\text { Being used as treatment for } \\
\text { several diseases such as cancer, } \\
\text { peritonitis and etc. }\end{array}$ & {$[52-55]$} \\
\hline Schizophyllan & $\begin{array}{l}\text { Beta-1,3 and } \\
\text { beta-1,6-glucan }\end{array}$ & $\begin{array}{l}\text { Fungus } \\
\text { (Athelia rolfsii) }\end{array}$ & $\begin{array}{l}\text { Stimulate the } \\
\text { immune system, } \\
\text { carry metals in } \\
\text { water }\end{array}$ & $\begin{array}{l}\text { Aid in delivering drugs } \\
\text { and genes, and use in } \\
\text { some nanofibers }\end{array}$ & {$[56-59]$} \\
\hline
\end{tabular}


Some in vitro experiments have demonstrated that large beta-glucans or some of their particular ones (like zymosan) can cause activation of leukocytes and stimulate some of their activities such as phagocytosis, cytotoxicity, and antimicrobial actions. Intermediate or low molecular weight beta-glucans such as glucan phosphate can have biological activities in vivo, but still, their influence on cancer cells is unclear. Very short bglucans like laminarin are generally believed to be inactive [64-66]. In general, some functions are attributed to these polymers: they can have an activate macrophages and thereby increase the secretion of cytokines such as interleukin 1 (IL-1), IL-6, IL-8, IL-12, and tumor necrosis factor- $\alpha$ (TNF- $\alpha$ ) and inflammatory mediators [67]. Therefore, beta-glucans can influence on immune defense system. Moreover, investigations on the plasma amounts of beta-glucans showed that they can be involved in the mammal's defense mechanism against the fungal infections $[68,69]$. Apart from activating macrophages, $T$ cells, and natural killer cells, and complement can be activated by beta-glucans by the means of an alternative activation pathway, as well [70]. Beside the impacts of beta-glucans on immune system, beta-glucans are able to decrease the levels of insulin, blood sugar, and cholesterol by remaining inside the colon and intestine (oat and barley beta-glucans) [60]. Recently, new studies are have assessed the effects of these polymers on tumor cells and they suggested that beta-glucans can be proper candidates in the cancer therapy due to two reasons including their anti-cancer activities and immune system modulatory roles [23]. This review is an attempt to find an answer to this question: "do betaglucans have any impact on cervical cancer?"

\section{How do beta-glucans function?}

The focus of recent researches has been on the interaction between beta-glucans and their receptors, which are located on the cell surface, and how they allow these polymers to affect on the cells and make some alterations. Generally, glucan receptors can be expressed on macrophages, natural killer cells and neutrophils [23], however monocytes are the first cells in which betaglucan receptors were found [71]. There are four different receptors for beta-glucans including complement receptor 3 or CR3 [72], lactosylceramide [73], selected scavenger receptors [74], and dectin-1 (bGR) [75]. The CR3 is a glycoprotein dimer and consists of two subunits: a CD18 beta chain, which is noncovalently linked to one type of three alpha chains (which can be CD11a, $\mathrm{b}$ or c). This glycoprotein is a member of the beta integrin family and acts as a transmembrane glycoprotein. CR3 is mostly found on the plasma membrane of the phagocytic cells like neutrophils and NK cells, monocytes and less on macrophages. Functions of CR3 can be different in its resting or activated state but mediating phagocytosis, cytotoxic reactions, and cellular adhesion are counted as its main functions [76].

Lactosylceramide is a kind of glycosphingolipid which is expressed on the membranes of many cells of the body. This receptor has many functions including induction of the inflammatory protein in the macrophages (called MIP-2), activation of nuclear factor $-\kappa B$ (NF-kB), improvement of oxidative stress in the neutrophils and some antimicrobial activities. Although the real mechanisms of these receptors are still unclear [73]. Selected scavenger receptors are a part of predetermined pattern recognition receptors (PRRs) that in spite of the adaptive immunity do not identify the host products. They are involved in the innate immune system and are used to recognize the microorganisms by their unique carbohydrates, lipids, and proteins. Dectin-1 or beta-glucan receptor (bGR) is a type II transmembrane protein and it is able to attach to two kinds of glucans: $\beta-1,3$ and $\beta-1,6$. This receptor is mostly expressed on cells in the innate immune system and the main role of it is recognizing the yeast and fungi pathogens. The tail of this receptor consists of an immunoreceptor tyrosine-based activation motif (ITAM). Some functions are found for this receptor-like including stimulating the release of arachidonic acid, which is an important factor for producing some substances during the process of acute inflammation. Moreover, it is proven that it participates with toll-like receptor 2 and thereby induces the pro-inflammatory response of macrophages in mycobacterial infections [77-80].

\section{Beta-glucan and cancer}

Beta-glucans have complicated structures and because of that, they have several pivotal roles in human body such as increasing resistance to infectious challenges [23], anti-carcinogenic activities [81, 82], anti-tumor effects [61], and activating leukocytes, T helpers, and NK cells [83], anticoagulant effects [84], and antibiotic impacts [85]. Generally, three kinds of study that investigated the role of beta-glucans as a modulator for the immune system:

1) In vitro studies: several studies have proven that beta-glucans can act as an enhancer for macrophages and neutrophils [86-88]. This function is possible because they can make an elevation to the production of chemokine and pro-inflammatory cytokines and can augment the oxidative burst [86, 89-91]. Olson et al. [89] revealed that $S$. cerevisiae can affect on the alveolar macrophages and cause an elevation in the amounts of TNF- $\alpha$ production in rats. Another study demonstrated that zymosan is able to induce the secretion of TNF- $\alpha$ [92]. Scientists have observed that adding the combination of soluble yeast beta-glucan 
and lipopolysaccharides (LPS), which are a part of pathogen-associated molecular patterns, to the whole human blood could increase the concentration of TNF- $\alpha$, IL-8, IL-10, and tissue factor (TF) [93]. Additionally, these impacts are also proven for fungi, yeast, and oat beta-glucans. Estrada et al. [94] observed an augmentation in the production of IL-1a in murine macrophages because of oat beta-glucans and also detected an improvement in the secretion of IL2, IFN-gamma, and IL-4. Augmenting the activity of leukocytes is a function of PGG or poly-[1, 6]-D-glucopyranosil-[1,3]-D-glucoyranose which is extracted from yeast. This beta-glucan makes neutrophils migrate more toward C5a and it induces the stimulating responses of the immune system with no effects on the production of cytokines involved in inflammation [95]. Dendritic cells are a kind of antigen-presenting cells, which Lin et al. [96] discovered the impact of fungal beta-glucan P-SG on them. They revealed that it results in stimulation in T helper - 1 type of cytokine response. Furthermore, beta-glucans not only can affect on leukocytes but they also can induce epithelial cells response. For example, pneumocystis carinii beta-glucan is able to stimulate the alveolar epithelial cells in rats to secret macrophage inflammatory protein-2 [97]. Taken together, beta-glucans modulate the response of the immune system by cytokine secretion regulating. Another in vitro study found that maitake mushroom betaglucan can induce apoptosis in prostate cancer cells by affecting on oxidative stress. Tian et al. [98] also revealed that beta-glucans are able to abolish the myeloid-derived suppressor cells. Myeloid-derived suppressor cells or MDSCs suppress the immune system and induce tumor progression. Thus, betaglucans via abrogating them help the anti-tumor responses of the immune system. A report also confirmed the down-regulation effect of beta-glucans on another unit that has the immunosuppressor effects on regulatory T cells (Tregs) [99].

2) Animal studies: many researchers have worked on isolated leukocytes which are extracted from an animal treated with beta-glucans. These studies, in agreement with in vitro studies, has also observed an elevation in production amounts of proinflammatory cytokine [100], in oxidative burst [101], and chemotaxis [102] and overall an induction in the specific immunity of type $1 \mathrm{~T}$ helpers and also an elevated survival rate against the infection of pathogens which can be concluded from this kind of researches [83].

3) Human studies: in spite of the numerous trials carried out in vitro and on animals, the number of human studies is limited. The only thing that these studies have shown is the decreased risk of being infected and the need for antibiotics in pretreatment of high-risk surgical patients [103, 104]. Another trial showed that zymosan stimulates the regulatory antigen-presenting cells and as well, increases the tolerance of the antigen-specific $\mathrm{T}$ cells. Moreover, beta-glucans extracted from Candida albicans cause an induction in the differentiation of monocytes into dendritic cells [105].

Role of beta-glucans in monoclonal antibodies (MABs)associated immunotherapy

In recent years, a novel therapeutic method has been discovered that is an insight for replacing chemo and radiotherapy with large amounts of toxicity and side effects in cancer treatment. The preference of this approach is because of its specific action that only affects the tumor cells and therefore it minimizes the surrounding tissue injury [23]. This new method is based on the activation of complement by using monoclonal antibodies. A group of antibodies which all of them are derived from the same Blymphocyte clone and are linked to each other is the definition of this kind of antibodies or mABs [106]. Direct destruction of tumor cells is the result of their role as an activator for the complement system. MABs direct the cell-killing impressions to a tumor cell by using three mechanisms including complement-dependent (CDC), antibody-dependent (ADCC), and CR3-dependent cytotoxicity (CR3-DCC). The CR3 is one of the beta-glucans receptors and hence, in order to be activated, it needs to be linked into a fungal or bacterial beta-glucan. Additionally, there is another ligand that binds to another site of CR3 and is essential for activating these receptors including iCR3b which is an antigen for tumor cells and coats them. Nevertheless, in spite of the microorganisms, tumor cells do not possess beta-glucans on their surface. Consequently, the exogenous beta-glucans are needed to induce this mechanism and so this method can be effective on tumor cells adjuvant with beta-glucans [107]. Some studies by administering beta-glucans orally [108] and intravenous [109] have found some significant results in this field.

\section{The impact of beta-glucans on myeloid-derived suppressor cells}

Myeloid-derived cells are a heterogeneous population. The mononuclear type of these cells includes macrophages, dendritic cells, and monocytes which are terminally differentiated. These cells in the case of inflammation differentiate into macrophages and dendritic cells. MDSC suppresses different kinds of immunity cells especially $\mathrm{T}$ cells and thereby their main function is suppressing the immune system in antigen-specific or non-specific manners. MDSC includes two classes of cells: granulocytic or polymorphonuclear (PMN-MDSC) and monocytic 
(M-MDSC) [110]. T reg cells, myeloid suppressor cells, and inhibitory cytokines are three considerable components of the immune system which cause the destruction of anti-tumor immunity [111]. Current investigations have informed another anti-cancer property for beta-glucans including abrogating MDSC. Albeituni et al. [112] indicated that particulate beta-glucans can corrupt both PMN-MDSC and M-MDSC by stimulating the apoptosis of the former and regulating the differentiation of the latter one into APC in cancer. As well, there are some other studies confirming the part of beta-glucans are able to inhibit the differentiation of MDSC [113, 114]. Rui et al. [115] considered a beta-glucan extracted from bacteria, curdlan, and its actions against the tumor progression and observed that curdlan is able to boost the MDSCs differentiation and therefore it decreases the number of immature MDSCs. This action of curdlan results in decreasing the suppressive impact of MDSCs against anti-tumor immunity. Furthermore, another group of researchers, Ning et al. [116], worked on a beta-glucan derived from the yeast Saccharomyces cerevisiae named WGP beta-glucan. They found that WGP not only can activate immature dendritic cells, T-helper 1, and differentiation of the cytotoxic $\mathrm{T}$ lymphocytes through dectin-1 signaling but it can also abolish the immune suppression caused by tumoreducated dendritic cells and improve priming of $\mathrm{T}$ cells. Taken together, WGP is another important beta-glucan in promoting anti-tumor immunity.

\section{Developmental mechanisms of cervical cancer}

As mentioned, the most crucial risk factor for cervical cancer is being infected by human papillomavirus or HPV (especially HPV 16) [117]. Till now, more than 100 types of HPV are discovered but only 40 types of them can infect the human genital area. HPV fragments include 8000 based-pair of long circular DNAs which are covered with a mantle of two proteins: L1 and L2. HPV also needs six other proteins (named E1, E2, and E4-E7) for replicating the viral DNA and the group of viral particles that are newly produced by the infected cell. Generally, HPV infects the differentiating epithelial cells of the skin or mucosae and consequently, it's completely adjusted to its host and utilizes the host's cellular mechanisms to achieve its own targets [13]. E6 and E7 are two kinds of viral proteins that have essential roles in the virus replication process [118] and so they can determine the risk of HPV types [119]. These two proteins exert their functions via interaction with some cellular proteins such as p53 and pRB (retinoblastoma protein, a tumor suppressor). P53 and pRB are central molecules for regulating the cell cycle and hence their mutation can have important roles in the initiation and progression of various diseases such as cancer [118]. The binding of E6 to p53 provides an end to the process of apoptosis [120] and by binding of E7 to pBR, the expression of the necessary proteins for the replication of the DNA is stimulated [118]. Throughout the cancer progression, the integration of the host chromosome and viral genome causes a persistent level of E6/E7 [121] and the constant activity of E6 and E7 can augment the instability of the genome, create an aggregation of oncogene mutations, destroy more and more the control of cell growth, and sooner or later cause cancer (mostly cervical cancer) [122].

\section{Beta-glucan and cervical cancer}

In our knowledge, beta-glucans have an anti-cancer property because of their immunomodulation role on $\mathrm{T}$ cells and antigen-presenting cells such as dendritic cells, macrophages, and B lymphocytes $[87,123,124]$. As a result, beta-glucans also might be effective in reducing cervical cancer progression through modulating both innate and adaptive immunity [123]. Several empirical studies have been conducted in order to investigate whether beta-glucans can be used as novel adjuvant treatment or prognosis approaches (Table 2).

Some efforts were made in the field of cervical cancer prevention and demonstrated that beta-glucans are also able to affect HPV infection. Stentella et al. [142] examined the carboxymethyl $\beta$-glucan (Colpofix ${ }^{\circ}$ ) gel on a group of people affected by CIN1. This case-control study demonstrated that Colpofix ${ }^{\circ}$ has an anti-cervical cancer role in regression of CIN1. In 2010, two studies were conducted on the subject of "the beta-glucans' influence on the HPV-correlated lesions in the genital area". The first study found that beta-glucans are able to treat the lesions related to HPV infection [143] and the second study revealed the efficacy of beta-glucan treatment for HPVCIN1 lesions [144]. These studies suggested that besides the anti-cancer effects of beta-glucans, they also have some effects on HPV infection, the main cause of cervical cancer.

Most of the recent researches on beta-glucans have been conducted on the sizofiran and its association with cervical cancer. Sizofiran or SPG is a beta-glucan that is derived from a mushroom called schizophyllun commune Fries [145]. The therapeutic anti-cancer impacts of sizofiran have been proven in murine and rats [146148]. A study shows that SPG does its function though increasing the infiltration of $\mathrm{T}$ cells and Langerhans cells (which are one kind of the antigen-presenting cells for $\mathrm{T}$ cell responses) $[134,149]$ and so SPG can be used for the treatment of advanced cervical cancer to prolong the patient's survival [133]. Nakano et al. [132] revealed that not only infiltration of Langerhans cells or ILC enhances $\mathrm{T}$ cell response also it can improve the local response to radiation treatment in cervical cancer. Shimizu et al. $[130,131]$ showed another function of SPG. They revealed that sizofiran is also able to enhance the function 
Table 2 Functions of diverse beta-glucans and their application in cervical cancer

\begin{tabular}{|c|c|c|c|c|}
\hline Beta-glucan & $\begin{array}{l}\text { Model (In vitro, In } \\
\text { vivo, Human) }\end{array}$ & Outcome (s) & $\begin{array}{l}\text { Application in cervical cancer } \\
\text { (Therapeutic / Prevention) }\end{array}$ & References \\
\hline$\overline{S P G}$ & Human study & $\begin{array}{l}\text { Promoting the recovery } \\
\text { of T lymphocytes and } \\
\text { natural killer cells }\end{array}$ & $\begin{array}{l}\text { Treatment (adjuvant to } \\
\text { radiotherapy) }\end{array}$ & {$[125]$} \\
\hline SPG & Human study & $\begin{array}{l}\text { Increasing the survival } \\
\text { and recurrence time }\end{array}$ & $\begin{array}{l}\text { Treatment (adjuvant to } \\
\text { immunotherapy) }\end{array}$ & [126] \\
\hline SPG & Human study & $\begin{array}{l}\text { stimulating a rapid } \\
\text { recovery of the } \\
\text { immunologic } \\
\text { parameters impaired } \\
\text { by radiotherapy }\end{array}$ & $\begin{array}{l}\text { Treatment (adjuvant to } \\
\text { radiotherapy) }\end{array}$ & [127] \\
\hline SPG & Human study & $\begin{array}{l}\text { Increasing the } \\
\text { survival and } \\
\text { recurrence time }\end{array}$ & $\begin{array}{l}\text { Treatment (in combination } \\
\text { with irradiation therapy) }\end{array}$ & [128] \\
\hline SPG & Human study & $\begin{array}{l}\text { Increasing the } \\
\text { number and secretion } \\
\text { of TNF, IL-1 and IFN-gamma }\end{array}$ & Treatment & [129] \\
\hline SPG & Human study & $\begin{array}{l}\text { Augmentation helper T } \\
\text { (Th) cell functions of } \\
\text { pelvic lymph nodes }\end{array}$ & Treatment & {$[130,131]$} \\
\hline SPG & Human study & $\begin{array}{l}\text { Increasing infiltration of } \\
\text { Langerhans cells and } \\
\text { improving local response } \\
\text { to radiation treatment }\end{array}$ & Treatment & [132] \\
\hline SPG & Human study & $\begin{array}{l}\text { Augmentation of } \\
\text { lymphocyte infiltration }\end{array}$ & Treatment & [133] \\
\hline SPG & Human study & $\begin{array}{l}\text { Augmentation of } \\
\text { lymphocyte and } \\
\text { Langerhans cell } \\
\text { infiltration }\end{array}$ & Treatment & [134] \\
\hline Curdlan & In vitro & $\begin{array}{l}\text { More cytotoxicity } \\
\text { and a broader } \\
\text { distribution of } \\
\text { loaded drug }\end{array}$ & $\begin{array}{l}\text { Treatment (as drug } \\
\text { carrier for epirubicin) }\end{array}$ & [135] \\
\hline LBE & In vitro & Anti-cancer effects & Treatment & [136] \\
\hline SCG & In vivo & $\begin{array}{l}\text { Enhancing the } \\
\text { hematopoietic } \\
\text { response, recovering } \\
\text { leukocyte population } \\
\text { in peritoneal cavity }\end{array}$ & Treatment & [137] \\
\hline PG101 & In vivo & $\begin{array}{l}\text { Induces the differentiation } \\
\text { of progenitor cells to } \\
\text { granulocytes and/or } \\
\text { proliferation of the } \\
\text { committed cells }\end{array}$ & Treatment & [138] \\
\hline Zymosan & In vivo & $\begin{array}{l}\text { Induction in the activity } \\
\text { of peritoneal macrophages }\end{array}$ & Treatment & [139] \\
\hline PBG & In vitro & $\begin{array}{l}\text { Affects on both humoral } \\
\text { and cellular immune } \\
\text { response by increasing } \\
\text { the cytotoxic and helper } \\
\text { T cells and the release } \\
\text { of IFN- } \gamma\end{array}$ & Treatment and prevention & [140] \\
\hline Lentinan & - & Increasing drug efficacy & $\begin{array}{l}\text { Treatment (combined with } \\
\text { cisplatin and docetaxel) }\end{array}$ & [141] \\
\hline
\end{tabular}

of helper $\mathrm{T}$ cells which are located in lymph nodes of pelvic in cervical cancer and additionally they observed an enhanced IL-2/IL-2R system. Chen et al. [129] discovered that SPG can elevate the secretion amounts of TNF, IFN-gamma, and IL-1 from peritoneal macrophages and thereby affect on the cancer progression. Furthermore, some papers are published about the usage of SPG as adjuvant therapy in the cervical cancer treatment. Hasegawa et al. [150] used a combination of radiotherapy and SPG as a treatment for cancer of the uterine cervix and observed that this adjuvant therapy leads to stimulating the cytotoxic function of macrophages and increasing the activity of natural killer cells. Okamura et al. [128] declared that using SPG can prolong the survival and recurrence time in these patients but its influence on different stages of the cancer is the same. Sizofiran is proven to cause a longer survival if used in combination with radiotherapy because it is able to develop a rapid recovery for immunologic parameters that radiotherapy destroys [125-127]. 
Curdlan is another polysaccharide in which some studies have been conducted on. It is a microbial beta-glucan that is derived from Agrobacterium spp. and is insoluble in water [151, 152]. Investigations showed that curdlan can play an inhibitory role against the infection of the AIDS virus and it also has some anti-coagulant functions in the blood. Besides all the roles discovered for curdlan, it appears to have low toxicity in vitro and in vivo [153, 154]. On top of that carboxymethylated curdlan or CMC is also known for its anti-tumor effects [155-157]. As well, Li et al. [135] synthesized cholesterol-conjugated carboxymethyl curdlan or CCMC which is a new kind of amphiphilic polymer and found that this polymer can be used in cancer treatment. Entrapping epirubicin or EPB which is a drug used in chemotherapy which in CCMC can dissolve it, lengthen its time of retention in the circulation of plasma, improve its therapeutic efficacy, and decrease its toxicity and so it has an importance in the cancer therapy as a novel carrier for epirubicin. Some other studies have demonstrated that also lentinan, a lentinula edodes-derived beta-glucan, can improve the efficacy of chemo and radiotherapy in many cancers including cervical cancer [158]. Ghosh et al. [136] also worked on effects of an ethanolic extract from Lenzities betulina named LBE on cervical cancer cell lines and observed anti-cancer effects against $\mathrm{HeLa}, \mathrm{CaSki}$, and $\mathrm{SiHa}$.

Roopngam and collogues investigated the Pleurotus Sajor-caju- $\beta$-glucan polysaccharides or PBG and identified that PBG can affect on both humoral and cellular immune response by increasing the cytotoxic and helper $\mathrm{T}$ cells and the release of the IFN- $\gamma$. Therefore it can be used as a vaccine with HPV16E7 for the prevention and treatment of cervical cancer [140]. A trial examined a beta-glucan derived from edible mushroom Sparassis crispa named SCG and found that SCG can boost the hematopoietic responses and leukocyte population in peritoneal cavity so this beta-glucan can be a candidate for being used adjuvant to chemotherapy but further specific researches on cervical cancer are needed [137]. Jin et al. [138] explored the PG101, an extracted from Lentinus lepideus, and declared that this beta-glucan not only has anti-cancer effects (such as increasing proliferation of the committed cells) also can repair the damaged bone marrows, a result of chemo radiotherapy, and that is why it can be used as an adjuvant with chemo and radiotherapy but still. Nevertheless, further investigations are needed to show its effects on cervical cancer. In addition, beta-glucans extracted from yeast can have an enhancer role in the proliferation of the hematopoietic cells, and it can promote recovery of the leukocytes which are damaged because of the sub-lethal irradiation [159]. Nikulina et al. [139] used zymosan after treatment with actinomycin D, karminomycin and bleomycin in mice and observed that zymosan can cause an induction in the activity of peritoneal macrophages and thus, it might have therapeutic application in cervical cancer. Moreover, there are two alternative approaches for cancer treatment which previously have attracted a lot of attention including mAB-based therapy and using MDSC suppressors. The efficacy of betaglucans has been significantly proven in both of these methods and hence, beta-glucans are counted as a potential therapy in many kinds of cancer. Considering the potential of both these two methods for being used generally in cancers (exclusive of the type of cancer), they are promising therapeutic approaches for cervical cancer as well. Nevertheless, further investigations are still needed to prove the efficacy of these methods in cervical cancer.

\section{Conclusions}

Beta-glucans are known as immune system modulators which they can affect on a wide range cells including $\mathrm{T}$ cells, macrophages, monocytes, and antigen-presenting cells (APCs) like dendritic cells and thereby they can impact both innate and adaptive immunities. Recent studies with focusing on their influence on cytotoxic and helper T cells, APCs, inflammatory pathways, and oxidative burst (by using reactive oxygen species to destroy cells.) have revealed that they can also have some anticancer properties. Even so the main mechanisms in which these glucans function are inducing the APCs and $\mathrm{T}$ cells and thereby activating the anti-tumor immune system and subverting the suppressors of this immune system by stimulating the differentiation of MDSCs. It is also worth to mention that a study represented an antioxidant effect of oat beta-glucans [160] but further investigations are needed to prove their role in cancer prevention by scavenging free radicals. Likewise, a mABbased therapy which is a medical progression into a new era of cancer treatment is only effective on tumor cells using adjuvant beta-glucans. The mentioned evidences have shown that sizofiran, zymosan, curdlan, PBG, and other beta-glucans can be employed in the prevention or treatment of cervical cancer. Generally, in cancer treatment, both chemo and radiotherapy have some side effects. One of the most important side effects of chemotherapy is neutropenia. Chemotherapeutic drugs disturb the process of the formation of the blood. Hence, chemotherapy has negative effects on the defense system of cancer patients and makes them susceptible to infections. Besides, radiotherapy has some side effects as well. It also leads to hematopoietic and immune damage. Thus, anemia, lymphocytopenia, thrombocytopenia, and granulocytopenia are the unpleasant consequences of radiotherapy [161]. A novel role of beta-glucans has been discovered in recovering hematopoiesis caused by injured bone marrow and so beta-glucans not only have anti-cancer impressions but also can be used adjuvant to common therapies for cancer to reduce their side effects 


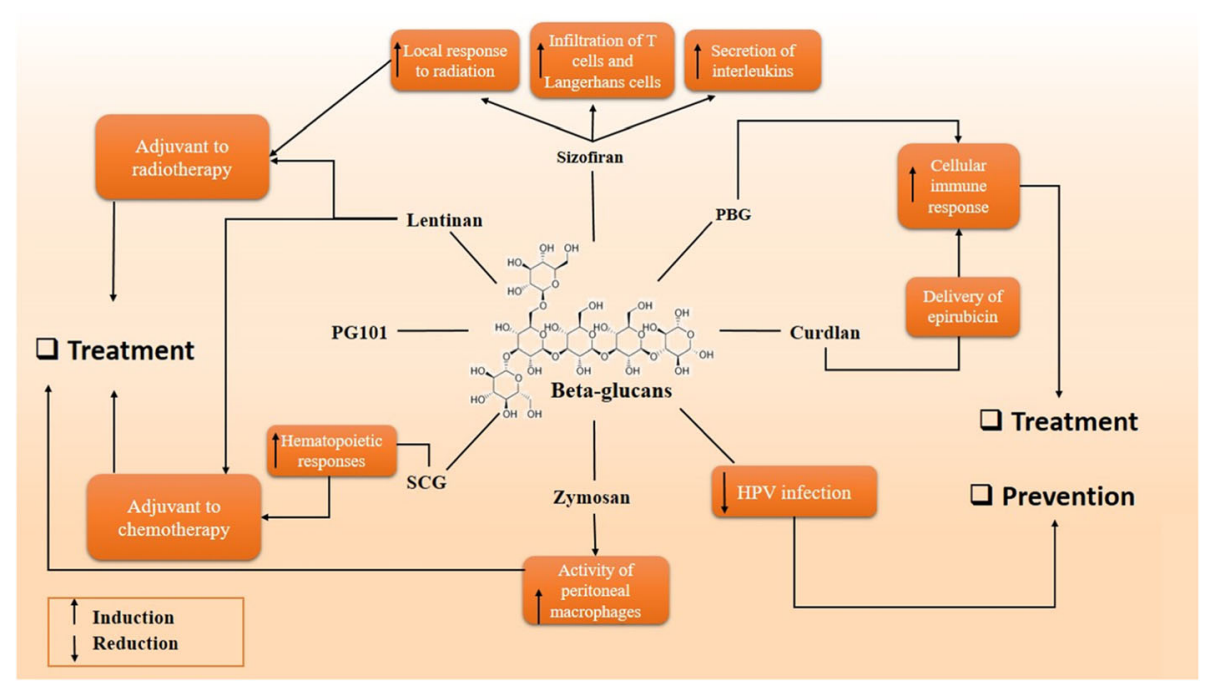

Fig. 1 Schematic representation in targeting different pathways using beta-glucans as a novel therapeutic approach in the treatment of cervical cancer

in a cancer patient's especially cervical cancer cases. Collectively, beta-glucans represent a novel promising therapeutic way for cervical cancer.

Taken together, it seems that further investigations are needed on beta-glucans to prove their toxicity on cervical cancer cells, non-toxicity on normal cells, and their ability for carrying drugs to the cancer site. We suggest that some beta-glucans such as pleuran, chrysolaminarian, laminarin, and zymosan which are not properly taken into consideration in the cervical cancer therapy field, might be convenient candidates for their characteristics such as anti-inflammatory activities and antioxidant impacts (Fig. 1). Moreover, further studies on delivering chemotherapeutic drugs by schizophyllan and curdlan might give new insight into cervical cancer therapy. More explorations on the influence of beta-glucans on the CR3 receptor cervical cancer cells would open new horizons for replacing dangerous common therapies with non-toxic treatments. In the prevention point of view, there is a need for more researches on the mechanisms by which beta-glucans influence HPV infection and also a need for more researches on delivering HPV proteins by beta-glucans as a vaccine.

\footnotetext{
Abbreviations

ADCC: Antibody-dependent cytotoxicity; BGR: Beta-glucan receptor;

CCMC: Cholesterol-conjugated carboxymethyl curdlan; CDC: Complement dependent cytotoxicity; CMC: Carboxymethylated curdlan; CR3: Complement receptor3; CR3-DCC: CR3-dependent cytotoxicity; EPB: Entrapping epirubicin; HPV: Human papillomavirus; IL-1: Interleukin-1; IL-2: Interleukin-2;

ILC: Infiltration of Langerhans cell; LPS: Lipopolysaccharide; mAB: Monoclonal antibody; MDSC: Myeloid-derived suppressor cells; PBG: Pleurotus Sajor-caju$\beta$-glucan; PGG: Poly-[1, 6]-D-glucopyranosil-[1, 3]-D-glucoyranose; PMNMDSC: Polymorphonuclear-myeloid derived suppressor cell;M-MDSC, monocytic-myeloid derived suppressor cell; pRB: Retinoblastoma protein; PRR: Pattern recognition receptor; TF: Tissue factor; Treg: Regulatory $T$ cell
}

\section{Acknowledgements}

Not applicable.

\section{Authors' contributions \\ The author(s) read and approved the final manuscript.}

\section{Funding}

Not applicable.

\section{Availability of data and materials}

Not applicable.

Ethics approval and consent to participate

This study was considered exempt by the KAUMS Institutional Review Board.

\section{Consent for publication}

Not applicable.

\section{Competing interests}

The authors declare that they have no competing interests.

\section{Author details}

${ }^{1}$ Pars Advanced and Minimally Invasive Medical Manners Research Center, Pars Hospital, Iran University of Medical Sciences, Tehran, Iran. ${ }^{2}$ Research Center for Biochemistry and Nutrition in Metabolic Diseases, Kashan University of Medical Sciences, Kashan, I.R, Iran. ${ }^{3}$ Anatomical Sciences Research Center, Kashan University of Medical Sciences, Kashan, Iran. ${ }^{4}$ Student Research Committee, Faculty of Public Health Branch, Iran University of Medical Sciences, Tehran, Iran.

Received: 22 July 2019 Accepted: 20 February 2020 2.

\section{References}

1. Sadri Nahand J, Moghoofei M, Salmaninejad A, Bahmanpour Z, Karimzadeh M, Nasiri M, Mirzaei HR, Pourhanifeh MH, Bokharaei-Salim F, Mirzaei H. Pathogenic role of exosomes and microRNAs in HPV-mediated inflammation and cervical cancer: A review. Int J Cancer. 2020;146(2):305-20.

2. Ghasemi F, Shafiee M, Banikazemi Z, Pourhanifeh MH, Khanbabaei H, Shamshirian A, Amiri Moghadam S, ArefNezhad R, Sahebkar A, Avan A, et al. Curcumin inhibits NF-kB and Wnt/beta-catenin pathways in cervical cancer cells. Pathol Res Pract. 2019;215(10):152556. 
3. Shafabakhsh R, Reiter RJ, Mirzaei H. Melatonin: A new inhibitor agent for cervical cancer treatment. J Cell Physiol. 2019;234(12):21670-82.

4. Nahand JS, Taghizadeh-Boroujeni S, Karimzadeh M, Borran S, Pourhanifeh MH, Moghoofei M, Bokharaei-Salim F, Karampoor S, Jafari A, Asemi Z, et al. microRNAs: New prognostic, diagnostic, and therapeutic biomarkers in cervical cancer. J Cell Physiol. 2019;234(10):17064-99.

5. Bosch FX, Lorincz A, Munoz N, Meijer CJ, Shah KV. The causal relation between human papillomavirus and cervical cancer. J Clin Pathol. 2002;55(4):244-65.

6. Cogliano V, Grosse Y, Baan R, Straif K, Secretan B, El Ghissassi F. Carcinogenicity of combined oestrogen-progestagen contraceptives and menopausal treatment. Lancet Oncology. 2005;6(8):552-3.

7. Smith JS, Green J, de Gonzalez AB, Appleby P, Peto J, Plummer M, Franceschi S, Beral V. Cervical cancer and use of hormonal contraceptives: a systematic review. Lancet. 2003;361(9364):1159-67.

8. Cancer ICoESoC. Carcinoma of the cervix and tobacco smoking: collaborative reanalysis of individual data on 13,541 women with carcinoma of the cervix and 23,017 women without carcinoma of the cervix from 23 epidemiological studies. Int J Cancer. 2006;118(6):1481-95.

9. Cancer ICoESoC. Cervical carcinoma and reproductive factors: collaborative reanalysis of individual data on 16,563 women with cervical carcinoma and 33,542 women without cervical carcinoma from 25 epidemiological studies. Int J Cancer. 2006;119(5):1108-24.

10. Smith JS, Herrero R, Bosetti C, Munoz N, Bosch FX, Eluf-Neto J, Castellsague X, Meijer CJ, Van den Brule AJ, Franceschi S. Herpes simplex virus-2 as a human papillomavirus cofactor in the etiology of invasive cervical cancer. J Natl Cancer Inst. 2002;94(21):1604-13.

11. Smith JS, Bosetti C, MUnoz N, Herrero R, Bosch FX, Eluf-Neto J, Meijer CJ, Van Den Brule AJ, Franceschi S, Peeling RW. Chlamydia trachomatis and invasive cervical cancer: a pooled analysis of the IARC multicentric casecontrol study. Int J Cancer. 2004;111(3):431-9.

12. Palefsky JM, Holly EA. Chapter 6: immunosuppression and co-infection with HIV. JNCI Monogr. 2003;2003(31):41-6.

13. Munoz N, Castellsague X, de Gonzalez AB, Gissmann L. Chapter 1: HPV in the etiology of human cancer. Vaccine. 2006;24(Suppl 3):S3/1-10.

14. Mirzaei HR, Sahebkar A, Salehi R, Nahand JS, Karimi E, Jaafari MR, Mirzaei H. Boron neutron capture therapy: moving toward targeted cancer therapy. J Cancer Res Ther. 2016;12(2):520-5.

15. Mirzaei H, Sahebkar A, Sichani LS, Moridikia A, Nazari S, Sadri Nahand J, Salehi H, Stenvang J, Masoudifar A, Mirzaei HR, et al. Therapeutic application of multipotent stem cells. J Cell Physiol. 2018;233(4):2815-23.

16. Saadatpour Z, Bjorklund G, Chirumbolo S, Alimohammadi M, Ehsani $H$, Ebrahiminejad H, Pourghadamyari H, Baghaei B, Mirzaei HR, Sahebkar A, et al. Molecular imaging and cancer gene therapy. Cancer Gene Ther. 2016. https://doi.org/10.1038/cgt.2016.62.

17. Hashemi Goradel N, Ghiyami-Hour F, Jahangiri S, Negahdari B, Sahebkar A, Masoudifar A, Mirzaei H. Nanoparticles as new tools for inhibition of cancer angiogenesis. J Cell Physiol. 2018;233(4):2902-10.

18. Mirzaei H, Sahebkar A, Jaafari MR, Hadjati J, Javanmard SH, Mirzaei HR, Salehi R. PiggyBac as a novel vector in cancer gene therapy: current perspective. Cancer Gene Ther. 2016;23(2-3):45-7.

19. Mirzaei HR, Mirzaei H, Lee SY, Hadjati J, Till BG. Prospects for chimeric antigen receptor (CAR) gammadelta T cells: a potential game changer for adoptive T cell cancer immunotherapy. Cancer Lett. 2016;380(2):413-23.

20. Mohammadi M, Jaafari MR, Mirzaei HR, Mirzaei H. Mesenchymal stem cell: a new horizon in cancer gene therapy. Cancer Gene Ther. 2016;23(9):285-6.

21. Vora C, Gupta S. Targeted therapy in cervical cancer. ESMO Open. 2019; 3(Suppl 1):e000462.

22. Goodridge HS, Wolf AJ, Underhill DM. Beta-glucan recognition by the innate immune system. Immunol Rev. 2009;230(1):38-50.

23. Akramiene D, Kondrotas A, Didziapetriene J, Kevelaitis E. Effects of betaglucans on the immune system. Medicina (Kaunas). 2007;43(8):597-606.

24. Vandamme E, De Baets S, Vanbaelen A, Joris K, De Wulf P. Improved production of bacterial cellulose and its application potential. Polym Degrad Stab. 1998;59(1-3):93-9.

25. Lin W-C, Lien C-C, Yeh H-J, Yu C-M, Hsu S-h. Bacterial cellulose and bacterial cellulose-chitosan membranes for wound dressing applications. Carbohydr Polym. 2013;94(1):603-11.

26. Jonas R, Farah LF. Production and application of microbial cellulose. Polym Degrad Stab. 1998;59(1-3):101-6.

27. Ciechanska D. Multifunctional bacterial cellulose/chitosan composite materials for medical applications. Fibres Text East Eur. 2004;12(4):69-72.
28. Nevell TP, Zeronian SH. Cellulose chemistry and its applications; 1985.

29. Zhan X-B, Lin C-C, Zhang H-T. Recent advances in curdlan biosynthesis, biotechnological production, and applications. Appl Microbiol Biotechnol. 2012;93(2):525-31.

30. Zhang R, Edgar KJ. Properties, chemistry, and applications of the bioactive polysaccharide curdlan. Biomacromolecules. 2014;15(4):1079-96.

31. Sun Y, LiU Y, Li Y, LV M, Li P, Xu H, Wang L. Preparation and characterization of novel curdlan/chitosan blending membranes for antibacterial applications. Carbohydr Polym. 2011;84(3):952-9.

32. Kanke M, Tanabe E, Katayama H, KODA Y, Yoshitomi H. Application of curdlan to controlled drug delivery. III. Drug release from sustained release suppositories in vitro. Biol Pharm Bull. 1995;18(8):1154-8.

33. Kanke M, Koda K, Koda Y, Katayama H. Application of curdlan to controlled drug delivery. I. the preparation and evaluation of theophylline-containing curdlan tablets. Pharm Res. 1992;9(3):414-8.

34. Custódio CA, Reis RL, Mano JF. Photo-cross-linked laminarin-based hydrogels for biomedical applications. Biomacromolecules. 2016;17(5):1602-9.

35. Kadam S, O'Donnell C, Rai D, Hossain M, Burgess C, Walsh D, Tiwari B. Laminarin from Irish brown seaweeds Ascophyllum nodosum and Laminaria hyperborea: ultrasound assisted extraction, characterization and bioactivity. Marine Drugs. 2015;13(7):4270-80.

36. Kadam SU, Tiwari BK, O'Donnell CP. Extraction, structure and biofunctional activities of laminarin from brown algae. Int J Food Sci Technol. 2015;50(1): 24-31.

37. Aziz A, Poinssot B, Daire X, Adrian M, Bézier A, Lambert B, Joubert J-M, Pugin A. Laminarin elicits defense responses in grapevine and induces protection against Botrytis cinerea and Plasmopara viticola. Mol PlantMicrobe Interact. 2003;16(12):1118-28.

38. Carballo C, Chronopoulou EG, Letsiou S, Maya C, Labrou NE, Infante C, Power DM, Manchado M. Antioxidant capacity and immunomodulatory effects of a chrysolaminarin-enriched extract in Senegalese sole. Fish Shellfish Immunol. 2018;82:1-8.

39. Xia S, Gao B, Li A, Xiong J, Ao Z, Zhang C. Preliminary characterization, antioxidant properties and production of chrysolaminarin from marine diatom Odontella aurita. Marine Drugs. 2014;12(9):4883-97.

40. Yang $P$, Liang $M$, Zhang $Y$, Shen B. Clinical application of a combination therapy of lentinan, multi-electrode RFA and TACE in HCC. Adv Ther. 2008; 25(8):787.

41. Drandarska I, Kussovski V, Nikolaeva S, Markova N. Combined immunomodulating effects of BCG and Lentinan after intranasal application in Guinea pigs. Int Immunopharmacol. 2005;5(4):795-803.

42. Chihara G. Immunopharmacology of lentinan and glucans. In: Tissue Culture and Reticuloendothelial System: Proceedings of the Joint Congress of the European Tissue Culture Society and the European Reticuloendothelial Society, Held in Budapest, Hungary, 9-13 May 1983. Leiden: Brill Publishers; 1984. p. 179.

43. Zhang Y, Li S, Wang X, Zhang L, Cheung PC. Advances in lentinan: isolation, structure, chain conformation and bioactivities. Food Hydrocoll. 2011;25(2): 196-206.

44. Perlin A, Suzuki S. The structure of lichenin: selective enzymolysis studies. Can J Chem. 1962;40(1):50-6.

45. Hensel A. y-Propoxy-sulfo-lichenin, an antitumor polysaccharide derived from lichenin. Pharm Acta Helv. 1995;70(1):25-31.

46. Podterob A. Chemical composition of lichens and their medical applications. Pharm Chem J. 2008;42(10):582-8.

47. Hozova B, Kuniak L, Kelemenova B. Application of beta-D-glucans isolated from mushrooms Pleurotus ostreatus (Pleuran) and Lentinus edodes (Lentinan) for increasing the bioactivity of yoghurts. Czech J Food Sci-UZPI (Czech Republic). 2004;22(6):204-14.

48. Jesenak M, Urbancek S, Majtan J, Banovcin P, Hercogova J. $\beta$-Glucan-based cream (containing pleuran isolated from Pleurotus ostreatus) in supportive treatment of mild-to-moderate atopic dermatitis. J Dermatol Treat. 2016;27(4):351-4.

49. Maftoun P, Malek R, Abdel-Sadek M, Aziz R, Enshasy HE. Bioprocess for semiindustrial production of immunomodulator polysaccharide Pleuran by Pleurotus ostreatus in submerged culture; 2013.

50. Jesenak M, Hrubisko M, Majtan J, Rennerova Z, Banovcin P. Anti-allergic effect of Pleuran ( $\beta$-glucan from Pleurotus ostreatus) in children with recurrent respiratory tract infections. Phytother Res. 2014;28(3):471-4.

51. Majtán J, Kumar P, Koller J, Dragúńová J, Gabriž J. Induction of metalloproteinase 9 secretion from human keratinocytes by pleuran ( $\beta$-glucan from Pleurotus ostreatus). Zeitschrift für Naturforschung C. 2009;64(7-8):597-600. 
52. Cash JL, White GE, Greaves DR. Zymosan-induced peritonitis as a simple experimental system for the study of inflammation. Methods Enzymol. 2009; 461:379-96.

53. Randich A, Uzzell T, Cannon R, Ness TJ. Inflammation and enhanced nociceptive responses to bladder distension produced by intravesical zymosan in the rat. BMC Urol. 2006;6(1):2.

54. Watzlawick R, Kenngott EE, Liu FDM, Schwab JM, Hamann A. Antiinflammatory effects of IL-27 in zymosan-induced peritonitis: inhibition of neutrophil recruitment partially explained by impaired mobilization from bone marrow and reduced chemokine levels. PLoS One. 2015;10(9): e0137651.

55. Harrigan TJ, Abdullaev IF, Jourd'heuil D, Mongin AA. Activation of microglia with zymosan promotes excitatory amino acid release via volume-regulated anion channels: the role of NADPH oxidases. J Neurochem. 2008;106(6): 2449-62.

56. Zhang $Y$, Kong H, Fang Y, Nishinari K, Phillips GO. Schizophyllan: a review on its structure, properties, bioactivities and recent developments. Bioactive Carbohydrates Dietary Fibre. 2013;1(1):53-71.

57. Sakurai K, Kimura T, Koumoto K, Mizu M, Kobayashi R, Shinkai S. Application of schizophyllan as a novel gene carrier. In: Nucleic acids symposium series in Washington, DC. 2001;1(1):223-4. https://doi.org/10.1093/nass/1.1.223.

58. Abdel-Mohsen A, Abdel-Rahman RM, Fouda MM, Vojtova L, Uhrova L, Hassan A, Al-Deyab SS, El-Shamy IE, Jancar J. Preparation, characterization and cytotoxicity of schizophyllan/silver nanoparticle composite. Carbohydr Polym. 2014;102:238-45.

59. Grisel M, Muller G. Rheological properties of the Schizophyllan- borax system. Macromolecules. 1998;31(13):4277-81

60. Kumar P, Jain K, Munilkumar S, Chalal R. Beta Glucan: Avaluable Nutraceuticalfor promoting health in aquaculture (short review). Afr J Basic Appl Sci. 2013:5(5):220-7.

61. Chan GC, Chan WK, Sze DM. The effects of beta-glucan on human immune and cancer cells. J Hematol Oncol. 2009:2:25.

62. Bohn JA, JN BM. ( $1 \rightarrow 3)-\beta-D-G l u c a n s$ as biological response modifiers: a review of structure-functional activity relationships. Carbohydr Polym. 1995; 28(1):3-14.

63. Yadomae T. Structure and biological activities of fungal beta-1, 3-glucans. Yakugaku zasshi: J Pharmaceutical Soc Jpn. 2000;120(5):413-31.

64. Brown GD, Gordon S. Fungal beta-glucans and mammalian immunity. Immunity. 2003;19(3):311-5.

65. Ishibashi K, Miura NN, Adachi Y, Ohno N, Yadomae T. Relationship between solubility of grifolan, a fungal 1,3-beta-D-glucan, and production of tumor necrosis factor by macrophages in vitro. Biosci Biotechnol Biochem. 2001; 65(9):1993-2000.

66. Lee DY, Ji IH, Chang HI, Kim CW. High-level TNF-alpha secretion and macrophage activity with soluble beta-glucans from Saccharomyces cerevisiae. Biosci Biotechnol Biochem. 2002;66(2):233-8.

67. Kim GY, Choi GS, Lee SH, Park YM. Acidic polysaccharide isolated from Phellinus linteus enhances through the up-regulation of nitric oxide and tumor necrosis factor-alpha from peritoneal macrophages. J Ethnopharmacol. 2004;95(1):69-76.

68. Lavigne LM, Albina JE, Reichner JS. Beta-glucan is a fungal determinant for adhesion-dependent human neutrophil functions. J Immunol. 2006;177(12): 8667-75.

69. Sato T, Iwabuchi K, Nagaoka I, Adachi Y, Ohno N, Tamura H, Seyama K, Fukuchi $Y$, Nakayama $H$, Yoshizaki $F$, et al. Induction of human neutrophil chemotaxis by Candida albicans-derived beta-1,6-long glycoside side-chainbranched beta-glucan. J Leukoc Biol. 2006;80(1):204-11.

70. Ross GD, Vetvicka V, Yan J, Xia Y, Vetvickova J. Therapeutic intervention with complement and beta-glucan in cancer. Immunopharmacology. 1999;42(13):61-74.

71. Czop JK, Austen KF. A beta-glucan inhibitable receptor on human monocytes: its identity with the phagocytic receptor for particulate activators of the alternative complement pathway. J Immunol. 1985;134(4):2588-93.

72. Thornton BP, Vĕtvicka V, Pitman M, Goldman RC, Ross GD. Analysis of the sugar specificity and molecular location of the beta-glucan-binding lectin site of complement receptor type 3 (CD11b/CD18). J Immunol. 1996;156(3): $1235-46$.

73. Zimmerman JW, Lindermuth J, Fish PA, Palace GP, Stevenson TT, DeMong DE. A novel carbohydrate-glycosphingolipid interaction between a beta-(13)-glucan immunomodulator, PGG-glucan, and lactosylceramide of human leukocytes. J Biol Chem. 1998;273(34):22014-20.
74. Rice PJ, Kelley JL, Kogan G, Ensley HE, Kalbfleisch JH, Browder IW, Williams DL. Human monocyte scavenger receptors are pattern recognition receptors for (1-->3)-beta-D-glucans. J Leukoc Biol. 2002;72(1):140-6.

75. Brown GD, Gordon S. A new receptor for $\beta$-glucans. Nature. 2001; 413(6851):36-7.

76. Lukacsi S, Nagy-Balo Z, Erdei A, Sandor N, Bajtay Z. The role of CR3 (CD11b/ CD18) and CR4 (CD11C/CD18) in complement-mediated phagocytosis and podosome formation by human phagocytes. Immunol Lett. 2017;189:64-72.

77. Brown GD, Taylor PR, Reid DM, Willment JA, Williams DL, Martinez-Pomares L, Wong SY, Gordon S. Dectin-1 is a major beta-glucan receptor on macrophages. J Exp Med. 2002;196(3):407-12.

78. Taylor PR, Brown GD, Reid DM, Willment JA, Martinez-Pomares L, Gordon S, Wong SY. The $\beta$-glucan receptor, dectin-1, is predominantly expressed on the surface of cells of the monocyte/macrophage and neutrophil lineages. J Immunol. 2002;169(7):3876-82.

79. Suram S, Brown GD, Ghosh M, Gordon S, Loper R, Taylor PR, Akira S, Uematsu S, Williams DL, Leslie CC. Regulation of cytosolic phospholipase A2 activation and cyclooxygenase 2 expression in macrophages by the $\beta$ glucan receptor. J Biol Chem. 2006;281(9):5506-14.

80. Yadav M, Schorey JS. The $\beta$-glucan receptor dectin-1 functions together with TLR2 to mediate macrophage activation by mycobacteria. Blood. 2006; 108(9):3168-75.

81. Barbisan LF, Spinardi-Barbisan ALT, Moreira ELT, Salvadori DMF, Ribeiro LR, AFd E, JLV d C. Agaricus blazei (Himematsutake) does not alter the development of rat diethylnitrosamine-initiated hepatic preneoplastic foci. Cancer Sci. 2003:94(2):188-92.

82. Barbisan L, Miyamoto M, Scolastici C, Salvadori DMF, Ribeiro L, Eira A, de Camargo JLV. Influence of aqueous extract of Agaricus blazei on rat liver toxicity induced by different doses of diethylnitrosamine. J Ethnopharmacol. 2002;83(1-2):25-32

83. Volman JJ, Ramakers JD, Plat J. Dietary modulation of immune function by beta-glucans. Physiol Behav. 2008;94(2):276-84.

84. Mantovani MS, Bellini MF, Angeli JP, Oliveira RJ, Silva AF. Ribeiro LR: betaGlucans in promoting health: prevention against mutation and cancer. Mutat Res. 2008;658(3):154-61.

85. Liang J, Melican D, Cafro L, Palace G, Fisette L, Armstrong R, Patchen ML. Enhanced clearance of a multiple antibiotic resistant Staphylococcus aureus in rats treated with PGG-glucan is associated with increased leukocyte counts and increased neutrophil oxidative burst activity. Int J Immunopharmacol. 1998;20(11):595-614.

86. Williams DL. Overview of (1-->3)-beta-D-glucan immunobiology. Mediat Inflamm. 1997:6(4):247-50.

87. Tzianabos AO. Polysaccharide immunomodulators as therapeutic agents: structural aspects and biologic function. Clin Microbiol Rev. 2000;13(4):523-33.

88. Zeković DB, Kwiatkowski S, Vrvić MM, Jakovljević D, Moran CA. Natural and modified $(1 \rightarrow 3)-\beta-D-g l u c a n s$ in health promotion and disease alleviation. Crit Rev Biotechnol. 2005;25(4):205-30.

89. Olson EJ, Standing JE, Griego-Harper N, Hoffman OA, Limper AH. Fungal beta-glucan interacts with vitronectin and stimulates tumor necrosis factor alpha release from macrophages. Infect Immun. 1996;64(9):3548-54.

90. Young S-H, Ye J, Frazer DG, Shi X, Castranova V. Molecular mechanism of tumor necrosis factor-a production in $1 \rightarrow 3-\beta$-glucan (zymosan)-activated macrophages. J Biol Chem. 2001;276(23):20781-7.

91. Adachi Y, Okazaki M, Ohno N, Yadomae T. Enhancement of cytokine production by macrophages stimulated with $(1 \rightarrow 3)$ - $\beta$-D-glucan, grifolan (GRN), isolated from Grifola frondosa. Biol Pharm Bull. 1994;17(12):1554-60.

92. Brown GD, Herre J, Williams DL, Willment JA, Marshall AS, Gordon S. Dectin-1 mediates the biological effects of $\beta$-glucans. J Exp Med. 2003;197(9):1119-24.

93. Engstad CS, Engstad RE, Olsen J-O, Østerud B. The effect of soluble $\beta-1,3-$ glucan and lipopolysaccharide on cytokine production and coagulation activation in whole blood. Int Immunopharmacol. 2002;2(11):1585-97.

94. Estrada A, Yun C-H, Kessel AV, Li B, Hauta S, Laarveld B. Immunomodulatory activities of oat $\beta$-glucan in vitro and in vivo. Microbiol Immunol. 1997; 41(12):991-8.

95. Wakshull E, Brunke-Reese D, Lindermuth J, Fisette L, Nathans RS, Crowley JJ, Tufts JC, Zimmerman J, Mackin W, Adams DS. PGG-Glucan, a soluble $\beta-(1,3)$ glucan, enhances the oxidative burst response, microbicidal activity, and activates an NF-KB-like factor in human PMN: evidence for a glycosphingolipid $\beta$-(1, 3)-glucan receptor. Immunopharmacology. 1999;41(2):89-107.

96. Lin Y-L, Lee S-S, Hou S-M, Chiang B-L. Polysaccharide purified from Ganoderma lucidum induces gene expression changes in human dendritic 
cells and promotes Thelper 1 immune response in BALB/c mice. Mol Pharmacol. 2006;70(2):637-44.

97. Hahn PY, Evans SE, Kottom TJ, Standing JE, Pagano RE, Limper AH. Pneumocystis carinii cell wall $\beta$-glucan induces release of macrophage inflammatory protein-2 from alveolar epithelial cells via a lactosylceramidemediated mechanism. J Biol Chem. 2003;278(3):2043-50.

98. Tian J, Ma J, Ma K, Guo H, Baidoo SE, Zhang Y, Yan J, Lu L, Xu H, Wang S. $\beta$ Glucan enhances antitumor immune responses by regulating differentiation and function of monocytic myeloid-derived suppressor cells. Eur J Immunol. 2013;43(5):1220-30.

99. Gabrilovich DI, Nagaraj S. Myeloid-derived suppressor cells as regulators of the immune system. Nat Rev Immunol. 2009;9(3):162

100. Abel G, CzoP JK. Stimulation of human monocyte $\beta$-glucan receptors by glucan particles induces production of TNF-a and IL-1 $\beta$. Int J Immunopharmacol. 1992;14(8):1363-73.

101. Błaszczyk K, Wilczak J, Harasym J, Gudej S, Suchecka D, Królikowski T, et al. Impact of low and high molecular weight oat beta-glucan on oxidative stress and antioxidant defense in spleen of rats with LPS induced enteritis. Food Hydrocolloid. 2015;51:272-80.

102. LeBlanc BW, Albina JE, Reichner JS. The effect of PGG- $\beta$-glucan on neutrophil chemotaxis in vivo. J Leukoc Biol. 2006;79(4):667-75.

103. Babineau TJ, Hackford A, Kenler A, Bistrian B, Forse RA, Fairchild PG, Heard S, Keroack M, Caushaj P, Benotti P. A phase II multicenter, double-blind, randomized, placebo-controlled study of three dosages of an immunomodulator (PGG-glucan) in high-risk surgical patients. Arch Surg. 1994;129(11):1204-10.

104. Babineau TJ, Marcello P, Swails W, Kenler A, Bistrian B, Forse RA. Randomized phase $1 / /$ trial of a macrophage-specific immunomodulator (PGG-glucan) in high-risk surgical patients. Ann Surg. 1994;220(5):601.

105. Nisini R, Torosantucci A, Romagnoli G, Chiani P, Donati S, Gagliardi MC, Teloni R, Sargentini V, Mariotti S, Iorio E. ß-Glucan of Candida albicans cell wall causes the subversion of human monocyte differentiation into dendritic cells. J Leukoc Biol. 2007;82(5):1136-42.

106. Liu JK. The history of monoclonal antibody development - Progress, remaining challenges and future innovations. Ann Med Surg (Lond). 2014;3(4):113-6.

107. Gelderman KA, Tomlinson S, Ross GD, Gorter A. Complement function in mAb-mediated cancer immunotherapy. Trends Immunol. 2004;25(3):158-64.

108. Cheung N-KV, Ross GD, Hansen RD, Ostroff GR, Xing PX, Hong F, Yan J, Baran JT, Allendorf DJ. Mechanism by which orally administered. J Immunol. 2004;173:797-806.

109. Hong F, Hansen RD, Yan J, Allendorf DJ, Baran JT, Ostroff GR, Ross GD. $\beta$ Glucan functions as an adjuvant for monoclonal antibody immunotherapy by recruiting tumoricidal granulocytes as killer cells. Cancer Res. 2003;63(24): 9023-31.

110. Gabrilovich DI. Myeloid-Derived Suppressor Cells. Cancer Immunol Res. 2017;5(1):3-8.

111. Sica A, Massarotti M. Myeloid suppressor cells in cancer and autoimmunity. J Autoimmun. 2017:85:117-25.

112. Albeituni SH, Ding C, Liu M, Hu X, Luo F, Kloecker G, Bousamra M 2nd, Zhang $\mathrm{HG}$, Yan J. Yeast-derived particulate beta-Glucan treatment subverts the suppression of myeloid-derived suppressor cells (MDSC) by inducing Polymorphonuclear MDSC apoptosis and Monocytic MDSC differentiation to APC in cancer. J Immunol. 2016;196(5):2167-80.

113. Anani W, Shurin MR. Targeting myeloid-derived suppressor cells in Cancer Adv Exp Med Biol. 2017;1036:105-28.

114. Tian J, Ma J, Ma K, Guo H, Baidoo SE, Zhang Y, Yan J, Lu L, Xu H, Wang S. Beta-Glucan enhances antitumor immune responses by regulating differentiation and function of monocytic myeloid-derived suppressor cells. Eur J Immunol. 2013;43(5):1220-30.

115. Rui K, Tian J, Tang X, Ma J, Xu P, Tian X, Wang Y, Xu H, Lu L, Wang S. Curdlan blocks the immune suppression by myeloid-derived suppressor cells and reduces tumor burden. Immunol Res. 2016;64(4):931-9.

116. Ning $Y, X u$ D, Zhang $X$, Bai $Y$, Ding J, Feng T, Wang S, Xu N, Qian K, Wang $Y$, et al. beta-glucan restores tumor-educated dendritic cell maturation to enhance antitumor immune responses. Int J Cancer. 2016;138(11):2713-23.

117. Walboomers JM, Jacobs MV, Manos MM, Bosch FX, Kummer JA, Shah KV, Snijders PJ, Peto J, Meijer CJ, Munoz N. Human papillomavirus is a necessary cause of invasive cervical cancer worldwide. J Pathol. 1999;189(1):12-9.

118. Münger K, Baldwin A, Edwards KM, Hayakawa H, Nguyen CL, Owens M, Grace M, Huh K. Mechanisms of human papillomavirus-induced oncogenesis. J Virol. 2004;78(21):11451-60.
119. Longworth MS, Laimins LA. Pathogenesis of human papillomaviruses in differentiating epithelia. Microbiol Mol Biol Rev. 2004;68(2):362-72.

120. Thomas M, Pim D, Banks L. The role of the E6-p53 interaction in the molecular pathogenesis of HPV. Oncogene. 1999;18(53):7690.

121. Bernard H-U. Gene expression of genital human papillomaviruses and considerations on potential antiviral approaches. Antivir Ther. 2002;7(4):219-37.

122. Duensing S, Münger K. Mechanisms of genomic instability in human cancer: insights from studies with human papillomavirus oncoproteins. Int I Cancer. 2004;109(2):157-62.

123. Roopngam PE. Increased response of human T-lymphocytes by dendritic cells pulsed with HPV16E7 and Pleurotus sajor-caju-beta-glucan (PBG). Iran J Immunol. 2018;15(4):246-55.

124. Lanzavecchia A. Receptor-mediated antigen uptake and its effect on antigen presentation to class II-restricted T lymphocytes. Annu Rev Immunol. 1990;8(1):773-93.

125. Sekiguchi I, Suzuki M, Izumi A, Aida I, Tamada T. The study on the immunological effect of sizofilan combined with radiotherapy in patients with uterine cervical cancer. Nihon Gan Chiryo Gakkai Shi. 1990;25(11):2659-64.

126. Okamura K, Hamazaki Y, Yajima A, Noda K. Adjuvant immunotherapy: two randomized controlled studies of patients with cervical cancer. Biomed Pharmacother. 1989:43(3):177-81.

127. Miyazaki K, Mizutani H, Katabuchi H, Fukuma K, Fujisaki S, Okamura H. Activated (HLA-DR+) T-lymphocyte subsets in cervical carcinoma and effects of radiotherapy and immunotherapy with sizofiran on cell-mediated immunity and survival. Gynecol Oncol. 1995;56(3):412-20.

128. Okamura K, Suzuki M, Chihara T, Fujiwara A, Fukuda T, Goto S, Ichinohe K, Jimi S, Kasamatsu T, Kawai N, et al. Clinical evaluation of schizophyllan combined with irradiation in patients with cervical cancer. A randomized controlled study. Cancer. 1986;58(4):865-72.

129. Chen JT, Teshima H, Shimizu Y, Hasumi K, Masubuchi K, Suzuki M. Sizofiran and recombinant interferon gamma stimulate peritoneal macrophages obtained from patients with gynecologic malignancies-increased secretion of tumor necrosis factor, LL-1 and interferon-gamma. Gan To Kagaku Ryoho. 1990;17(7):1365-9.

130. Shimizu Y, Teshima H, Chen JT, Fujimoto I, Hasumi K, Masubuchi K. Augmentative effect of sizofiran on the immune functions of regional lymph nodes in patients with cervical cancer. Nihon Sanka Fujinka Gakkai Zasshi. 1991:43(6):581-8.

131. Shimizu Y, Hasumi K, Masubuchi K. Augmenting effect of sizofiran on the immunofunction of regional lymph nodes in cervical cancer. Cancer. 1992. 69(5):1184-94

132. Nakano T, Oka K, Sugita T, Tsunemoto H. Antitumor activity of Langerhans cells in radiation therapy for cervical cancer and its modulation with SPG administration. In Vivo. 1993;7(3):257-63.

133. Gorai I, Yanagibashi T, Minaguchi H. Immunological modulation of lymphocyte subpopulation in cervical cancer tissue by Sizofiran and OK-432. Gynecol Oncol. 1992;44(2):137-46.

134. Nakano T, Oka K, Hanba K, Morita S. Intratumoral administration of sizofiran activates Langerhans cell and T-cell infiltration in cervical cancer. Clin Immunol Immunopathol. 1996;79(1):79-86.

135. Li L, Gao F-p, Tang H-b, Bai Y-g, Li R-f, Li X-m, Liu L-r, Wang Y-s, Zhang Q-q. Self-assembled nanoparticles of cholesterol-conjugated carboxymethyl curdlan as a novel carrier of epirubicin. Nanotechnology. 2010;21(26): 265601.

136. Ghosh SK, Sanyal T. Anti-cancer property of Lenzites betulina (L) Fr. on cervical cancer cell lines and its anti-tumor effect on HeLa-implanted mice. BioRxiv. 2019:540567. https://doi.org/10.1101/540567.

137. Harada T, Miura N, Adachi Y, Nakajima M, Yadomae T, Ohno N. Effect of SCG, 1, 3- $\beta$-D-glucan from Sparassis crispa on the hematopoietic response in cyclophosphamide induced leukopenic mice. Biol Pharm Bull. 2002;25(7): 931-9.

138. Jin M, Jeon H, Jung HJ, Kim B, Shin SS, Choi JJ, Lee JK, Kang CY, Kim S. Enhancement of repopulation and hematopoiesis of bone marrow cells in irradiated mice by oral administration of PG101, a water-soluble extract from Lentinus lepideus. Exp Biol Med (Maywood). 2003;228(6):759-66.

139. Nikulina LB. Effect of actinomycin D, carminomycin and bleomycin and their joint use with serotonin and zymosan on the functional state of the peritoneal macrophages. Antibiotiki. 1978;23(6):543-8.

140. Roopngam PE. Increased response of human T-lymphocytes by dendritic cells pulsed with HPV16E7 and Pleurotus sajor-caju- $\beta$-glucan (PBG). Iran J Immunol. 2018;15(4):246-55. 
141. Xiang D, Luo R. Effect of lentinan on the efficacy of docetaxel combined with cisplatin in stage IV cervical cancer. Oncol Prog. 2016;14(8):808-10.

142. Stentella P, Biamonti A, Carraro C, Inghirami P, Mancino P, Pietrangeli D, Votano S, Lazzari P, Medici C DE. Efficacy of carboxymethyl beta-glucan in cervical intraepithelial neoplasia: a retrospective, case-control study. Minerva Ginecol. 2017;69(5):425-30.

143. Pietrantoni E, Signore F, Berardi G, Donadio F, Donadio C. Role of betaglucan in the treatment of recurrent candidiasis and HPV-correlated lesions and reparative process of epidermis. Minerva Ginecol. 2010;62(1):1-5.

144. Scardamaglia P, Carraro C, Mancino P, Stentella P. Effectiveness of the treatment with beta-glucan in the HPV-CIN 1 lesions. Minerva Ginecol. 2010; 62(5):389-93.

145. Sugawara I, Lee KC, Wong M. Schizophyllan (SPG)-treated macrophages and anti-tumor activities against syngeneic and allogeneic tumor cells. Cancer Immunol Immunother. 1984:16(3):137-44.

146. Mizuhira V, Ono M, Yokofujita J, Kinoshita M, Asano T, Hase T, Amemiya K. Histological and cytochemical studies on the distribution of Schizophyllan Glucan (SPG) in cancer-inoculated animals. Acta Histochem Cytochem. 1985 18(2):221-54.

147. Komatsu N, OKuBo S, Kikumoto S, Kimura K, Saito G, Sakai S. Host-mediated antitumor action of schizophyllan, a glucan produced by Schizophyllum commune. GANN Jpn J Cancer Res. 1969:60(2):137-44.

148. Mashiba H, Matsunaga K. In vitro activation of human adherent cells by a glucan, Schizophyllan. Jpn J Exp Med. 1983;53(4):195-8.

149. Katz SI, Cooper KD, lijima M, Tsuchida T. The role of Langerhans cells in antigen presentation. J Investig Dermatol. 1985:85(1):S96-8.

150. Hasegawa K, Nishimura R, Kinugasa M, Okamura M, Kimura A, Ohtsu F, Takeuchi K, Mizuhira V. Electron microscopic and immunological studies concerning the effect on the antitumor activity of sizofiran (SPG) combined with radiotherapy for cervical cancer. Nihon Gan Chiryo Gakkai Shi. 1990; 25(10):2549-61.

151. Harada T, Misaki A, Saito H. Curdlan: a bacterial gel-forming $\beta-1$, 3-glucan. Arch Biochem Biophys. 1968;124:292-8.

152. McIntosh M, Stone BA, Stanisich VA. Curdlan and other bacterial (1-->3)beta-D-glucans. Appl Microbiol Biotechnol. 2005;68(2):163-73.

153. Yoshida T, Yasuda Y, Uryu T, Nakashima H, Yamamoto N, Mimura T, Kaneko Y. Synthesis and in vitro inhibitory effect of L-glycosyl-branched curdlan sulfates on AIDS virus infection. Macromolecules. 1994;27(22):6272-6.

154. Katsuraya K, Nakashima H, Yamamoto N, Uryu T. Synthesis of sulfated oligosaccharide glycosides having high anti-HIV activity and the relationship between activity and chemical structure. Carbohydr Res. 1999;315(3-4):234-42.

155. Sasaki T, Abiko N, Sugino Y, Nitta K. Dependence on chain length of antitumor activity of $(1 \rightarrow 3)-\beta$-D-glucan from Alcaligenes faecalis var. myxogenes, IFO 13140, and its acid-degraded products. Cancer Res. 1978; 38(2):379-83.

156. Saito H, Yoshioka Y, Uehara N, Aketagawa J, Tanaka S, Shibata Y Relationship between conformation and biological response for $(1 \rightarrow 3)-\beta-d-$ glucans in the activation of coagulation factor $\mathrm{G}$ from limulus amebocyte lysate and host-mediated antitumor activity. Demonstration of single-helix conformation as a stimulant. Carbohydr Res. 1991;217:181-90.

157. Sasaki T, Abiko N, Nitta K, Takasuka N, Sugino Y. Antitumor activity of carboxymethylglucans obtained by carboxymethylation of (1 leads to 3 )beta-D-glucan from Alcaligenes faecalis var. myxogenes IFO 13140. Eur J Cancer. 1979;15(2):211-5

158. Zhang M, Zhang Y, Zhang L, Tian Q. Mushroom polysaccharide lentinan for treating different types of cancers: a review of 12 years clinical studies in China. Prog Mol Biol Transl Sci. 2019;163:297-328.

159. Cramer DE, Allendorf DJ, Baran JT, Hansen R, Marroquin J, Li B, Ratajczak J, Ratajczak MZ, Yan J. B-Glucan enhances complement-mediated hematopoietic recovery after bone marrow injury. Blood. 2006;107(2):835-40.

160. Brindzova L, Certik M, Rapta P, Zalibera M, Mikulajova A, Takacsova M. Antioxidant activity, beta-glucan and lipid contents of oat varieties. Czech J Food Sci-UZPI (Czech Republic). 2009; 26(3):163-73.

161. Akramienè D, Kondrotas A, Didžiapetrienè J, Kèvelaitis E. Effects of B-glucans on the immune system. Medicina. 2007;43(8):597.

\section{Publisher's Note}

Springer Nature remains neutral with regard to jurisdictional claims in published maps and institutional affiliations.

Ready to submit your research? Choose BMC and benefit from:

- fast, convenient online submission

- thorough peer review by experienced researchers in your field

- rapid publication on acceptance

- support for research data, including large and complex data types

- gold Open Access which fosters wider collaboration and increased citations

- maximum visibility for your research: over $100 \mathrm{M}$ website views per year

At BMC, research is always in progress.

Learn more biomedcentral.com/submissions 